\title{
FUNCTIONAL ANALYSIS OF AGERATUM CONYZOIDES L. (BABANDOTAN) LEAVES EXTRACT ON RHEUMATOID ARTHRITIS MODEL RAT
}

\author{
ERNA HARFIANI ${ }^{1}$, RIRI NURUL SUCI ${ }^{1}$, KATRIN BASAH $^{1}$, ADE ARSIANTI $^{2}$, ANTON BAHTIAR $^{1 *}$
}

${ }^{1}$ Department of Pharmacology and Toxicology, Faculty of Pharmacy, Universitas Indonesia, Kampus UI Depok, Indonesia. ${ }^{2}$ Department of Medicinal Chemistry, Faculty of Medicine, Universitas Indonesia, Kampus UI Salemba, Jakarta, Indonesia. Email: anton.bahtiar@gmail.com

Received: 01 December 2016, Revised and Accepted: 26 December 2016

\section{ABSTRACT}

Objective: Rheumatoid arthritis (RA) is an autoimmune disease characterized by chronic inflammation in joints. Ageratum conyzoides L. (Babandotan) leaves are proven to be used in inflammation therapy, yet there is a little data regarding the effects of the leaves on RA. The aim of this study is to investigate anti-RA activity of the ethanolic extract of A. conyzoides L. leaves (EEAL) harvested from Bogor, Indonesia, in rats.

Methods: The phytochemical screening analysis and thin-layer chromatography were performed to analyze the constituents of the EEAL. This study used white male Sprague Dawley rats which were divided into 6 groups; normal control and negative control groups, both given $0.5 \%$ carboxymethyl cellulose; the positive control group, given methotrexate suspension $(0.05 \mathrm{mg} / 200 \mathrm{~g} \mathrm{bw}$.); the dose variation extract is $40 \mathrm{mg}, 80 \mathrm{mg}$, and $160 \mathrm{mg} / 200 \mathrm{~g}$ body weight. All the groups were induced with $0.1 \mathrm{ml}$ Complete Freund's adjuvant on day 1, except normal control group. Some parameters will be measured, such as paw edema, levels of leukocyte and lymphocyte, concentrations of tumor necrosis factor- $\alpha$ (TNF- $\alpha$ ), and the number of osteoclasts per $\mathrm{mm}^{2}$.

Results: For 21 days the rats have given treated the EEAL in three doses, was showed the decreasing volume of paw edema, levels of blood leukocytes and lymphocytes, concentrations of TNF- $\alpha$ and the number of osteoclasts, compared to the rat model of RA.

Conclusion: This study showed that the leaves of A. conyzoides L. harvested from Bogor, Indonesia, have activity as anti-RA in a rat model, in which flavonoid plays a role in inhibition of chronic inflammatory processes.

Keywords: Ageratum conyzoides L. leaves, Anti-rheumatoid arthritis, Complete Freund's adjuvant, Flavonoids.

(c) 2017 The Authors. Published by Innovare Academic Sciences Pvt Ltd. This is an open access article under the CC BY license (http://creativecommons. org/licenses/by/4. 0/) DOI: http://dx.doi.org/10.22159/ajpcr.2017.v10i3.16428

\section{INTRODUCTION}

Ageratum conyzoides L. (Asteraceae) (Babandotan), were harvested from Bogor, Indonesia, is widely grown in many tropical and subtropical countries in Africa, Asia, and the Americas [1-3]. Locally, this plant is used traditionally in Indonesia (including in Bogor) and the world, as a medicinal plant, especially for inflammation-related disease, yet there is a little data regarding the effects of $A$. conyzoides $\mathrm{L}$. leaves on rheumatoid arthritis (RA). A. conyzoides contain secondary metabolites such as flavonoids, tannins, alkaloids, saponins, terpenoids/steroids, and polyphenols [3-6]. The presence of these metabolites most found in the leaves, flowers, and in some parts of the plant [7].

Inflammation is a condition in which the body defends itself from injury or attack, such as microorganisms, or any other causes. Inflammation is a complex reaction which involves enzyme activation, cytokine production, extravasation of fluid, the influx of inflammatory cell, tissue breakdown, and repair process of the body. RA is a chronic inflammatory disease, primarily affects the joints and leads to the proliferation of the synovium, cartilage degradation, and bone erosion. The previous study has shown the pro-inflammatory cytokine, such tumor necrosis factor- $\alpha$ (TNF- $\alpha$ ), and interleukin-1 (IL-1) play an important role in the RA process [8-12]. Approximately, 1-2\% of the world population suffered from RA and cause impaired mobility, decreased labor productivity and increased health-care costs. In general, the treatment of RA use nonsteroidal anti-inflammatory drugs and a group of corticosteroids, yet both of these drugs only relieve the symptoms and do not cure the disease. Meanwhile, the drugs in the group of disease-modifying antirheumatic drugs, i.e., methotrexate which is currently known as the gold standard for the treatment of RA, as empirically proven to inhibit the progression of RA disease, yet still not cure the disease. In addition, the use of these drugs in the long-term can cause various side effects, such as gastrointestinal disorders (nausea, vomiting, abdominal discomfort, rash, and bleeding) $[11,13,14]$

Therefore, it is an important to get an alternative therapy which has a potential activity for the treatment of RA. This study offers a potential activity of $A$. conyzoides that are widely available in Indonesia and also scattered in several places in the world that can be used as an alternative/complementary therapies [3-5]. The objective of this study is to investigate the anti-RA activity of the ethanolic extract of A. conyzoides (Babandotan) leaves (EEAL) harvested from Bogor, Indonesia in rats.

\section{METHODS}

\section{Plant material and extract preparation}

A. conyzoides (Babandotan) leaves as the main material, obtained from the Research Institute for Spices and Medicinal Plants (BALITTR0), Bogor and determined by the Research Center for Biology, Indonesian Institute of Sciences (LIPI) (Certificate of Determination No. 206/IPH.1.01/If.07/I/2016). This plant was harvested from plants grown in Bogor, Indonesia (Bogor climatic: Temperature $21.8^{\circ} \mathrm{C}-30.4^{\circ} \mathrm{C}$ /average $26^{\circ} \mathrm{C}$, humidity $70 \%$, rainfall is quite high average 3,500-4,000 mm/year, and altitude 190-133 m above sea) [15]. Leaves are washed by running water, drained, dried, and ground into dry powder. The extraction method is use cold maceration using $70 \%$ ethanol (1:5) $(3 \times 24 \mathrm{hrs})$ to obtain a thick extract [16]. The results were obtained, weighed, and stored in dark glass bottles (yield: $16.2 \% \mathrm{w} / \mathrm{w}$ ). 
Drugs and chemicals

The chemicals used in the study is $70 \%$ ethanol solution (Brataco Chemistry, Indonesia), distilled water (Brataco Chemistry, Indonesia), neutral saline $0.9 \%$ (Otsuka, Indonesia), methotrexate (Ebewe Pharma, Austria), Complete Freund's adjuvant (CFA) containing Mycobacterium tuberculosis (Sigma-Aldrich, USA), and ketamine (Hameln, Germany).

\section{Animal}

The animal test uses Sprague Dawley rats which obtained from the IPB husbandry, Bogor. The weight of rats is between 175 and $250 \mathrm{~g}$. The rats were randomly divided into 6 groups with each group are consist of five rats. The group is conditioned in a cage under standard laboratory conditions, with a light cycle $12 \mathrm{~h}$ light on/12 h light off (dark), temperature $22^{\circ} \mathrm{C}-25^{\circ} \mathrm{C}$, humidity $40-60 \%$, the rats get access to food water freely, and do tag as identity. Acclimation is performed for 7 days and during the time conducted routine observations concerning the general condition and body weight. This research has certified by ethical certification of Faculty of Medicine, University of Indonesia (UI FK No. 75/UN2.F1/Ethics/2016) for the use of animals in experiments.

\section{Characterization of extract and chromatographic analysis}

The organoleptic examination results of the extract are has a greenish black color, specifically has a Babandotan odor and slightly bitter taste. The results of non-specific parametric of the EEAL are moisture content was $9 \%$, total ash content was $0.97 \%$, acid insoluble ash content was $0.04 \%$, and the levels of the solvent residue was negative (test using GC). Phytochemical screening observation found that the EEAL containing some chemicals metabolites such as flavonoids (produce a red color due to the addition of $\mathrm{Zn}$ and $\mathrm{Mg}$, and formed yellow bluish fluorescence using ultraviolet light $366 \mathrm{~nm}$ ), tannins (white deposits by giving gelatin and gelatin $+\mathrm{NaCl}$ ), alkaloids (solid white precipitate formed by providing reagents Mayer's, blackish brown color by giving reagent bouchardat), terpenoids steroids (bluish green color), and saponins (froth-formed with a diameter of $1.5 \mathrm{~cm}$ ). Total flavonoid was $2.31 \%$ by spectrophotometry. Thin-layer chromatography used silica plates F254 as the stationary phase for chromatographic characterization of the extract. A total of $10 \mathrm{mg}$ extract was weight and dissolved with $10 \mathrm{ml}$ of ethanol. And the mobile phase used toluene:Ethyl acetate:Formic acid at a ratio of 58:33:9, as well as equal with quercetin.

\section{Induction of arthritis with CFA}

A total of 30 rats (Sprague Dawley) were induced by CFA $(1 \mathrm{mg} / \mathrm{ml}$; $0.1 \mathrm{ml}$ ) and were injected in the left hind paw subcutaneously on the $1^{\text {st }}$ day and given a 4-week waiting period to form a rat model of RA [17], except for the normal control group. The rats were divided into 6 Groups (I-VI), each group was consist of five rats, i.e., Group I (normal control) and Group II (negative control) applied carboxymethyl cellulose 0.5\%, Group III (positive control) applied methotrexate $0.05 \mathrm{mg} / 200 \mathrm{~g} \mathrm{bw} / \mathrm{d}$ and Groups IV, V, and VI applied the EEAL in three different doses (40, 80, and $160 \mathrm{mg} / 200 \mathrm{~g}$ bw./d) during 21-day period. At day 29, rats were measured for paw edema volume, and level of leukocytes and lymphocytes. At day 50, rats were also measured for paw edema volume, the level of leukocytes and lymphocytes, and then measured for TNF- $\alpha$ concentration, and subsequently, rats were killed to evaluate the number of osteoclast at calcaneus bone.

\section{Examination of anti-inflammation activity}

Using mercury plethysmometer measurement, edema volume of left hind paw rats was observed and recorded before CFA injection on day 1 , and further observation on day 29 and 50 . The percentage of inhibition of paw edema volume was measured on day 50 , and the data were analyzed by comparing the outcomes between the 6 groups. The percentage inhibition of paw edema volume was calculated using the following formula:

$[(\mathrm{Vc}-\mathrm{Vt}) / \mathrm{Vc}] \times 100$

Where $\mathrm{Vc}$ is the average value of the paw edema volume by control group, and Vt is the average value of the paw edema volume by the test group [16].

\section{Measurement of blood leukocytes and lymphocytes levels}

Blood samples were collected from retro-orbital plexus on day 29 and 50 , mixed with ethylenediamin etetraacetic acid (EDTA) to prevent coagulation of blood and then measured with a hematology analyzer. Results of blood leukocyte and lymphocyte levels were recorded and analyzed.

\section{Measurement of TNF- $\alpha$ concentration}

Blood samples were collected from retro-orbital plexus on day 50, (without mixing with EDTA) and then measured with a hematology analyzer. The blood sample was stored at room temperature for $30 \mathrm{~min}$ and then centrifuged at $3.000 \mathrm{rpm}$ for $10 \mathrm{~min}$. The resulting serum was collected and stored at $-20^{\circ} \mathrm{C}$. The content of the cytokine TNF- $\alpha$ concentration was measured using enzyme-linked immunosorbent assay (ELISA) kit by applying optical density absorbance wavelengths of $450 \mathrm{~nm}$ and in accordance with manufacturer's procedures. ELISA reader shows the results and further data were analyzed.

\section{Measurement of number of osteoclasts}

In the previous study, we found that RA made bone resorption in the heel joint especially calcaneus bone [18]. Hence, we evaluated calcaneus bone by calculating osteoclast number on that bone. On the day 50 , the rats were set up to performed surgery to isolate the joints (region tibiotarsal) longitudinally midline [19]. The histopathology of calcaneus bone was made by fixation, decalcification, dehydration, purification, and infiltration/embedding in paraffin blocks, and cutting (3-5 $\mu \mathrm{m}$ ), finally stained by hematoxylin-eosin staining (H\&E). A number of osteoclasts at calcaneus bone were observed using a microscope $(\times 400)$. Osteoclasts are calculated based on the total number of osteoclasts per measuring area $\left(\mathrm{mm}^{2}\right)$ (Total Noc/Tar) and data were analyzed [20].

\section{RESULTS}

Phytochemical screening and chromatographic characterization Preliminary phytochemical screening revealed the presence of chemical metabolites such as flavonoids, tannins, alkaloids, terpenoids steroids, and saponins. Thin-layer chromatography appearance results showed flavonoids with $\mathrm{Rf}$ value was 0.53 , which almost equivalent to the standard solution, quercetin with Rf value was 0.52 . It indicated that in the EEAL, there were secondary metabolites such as flavonoids equivalent to quercetin (Fig. 1). The result showed that the EEAL characterization has met to the specification of Indonesian Herbal Pharmacopoeia [21-23].

\section{Effect on paw edema volume}

Anti-RA activity of the EEAL on rat paw edema induced by CFA $(n=5)$ is shown in Fig. 2a. Paw edema volume was measured by plethysmometer on day 29 and 50. On day 50 shown that the three EEAL doses can be reduced paw edema volume significantly $(\mathrm{p}<0.05)$ within 21 days treatment (in Dose I: 1.24; Dose II: 1.22; Dose III: 1.1) compared to edema volume for the negative control group (1.88). Edema inhibitory activity of the EEAL was found $34.04 \%$ in Dose I, $35.10 \%$ in Dose II, and $41.49 \%$ in Dose III on day $50^{\text {th }}$. The edema inhibitory activity was highest in doses of $160 \mathrm{mg} / 200 \mathrm{~g} \mathrm{bw}$./d of the EEAL but lower than positive control, methotrexate (53.19\%) (Fig. 2b). Application of the EEAL showed inhibitory activity edema in rats induced by CFA, and also showed the anti-inflammatory effect on chronic inflammation.

\section{Effect on level of blood leukocytes and lymphocytes}

Anti-RA activity of the EEAL is showed by the levels of blood leukocytes and lymphocytes are shown in Fig. 3. It is shown by observation on day 29 and 50 that the reducing of blood leukocytes levels caused by suppression of the EEAL activity compared to the negative control group; It obtained the results as follows: Dosage I: 13.6 and 13.7; Dosage II: 14.4 and 13.7; Dosage III: 14.2 and 11.5. Moreover, it was showed on day 50, the reducing of blood leukocytes level was significant seen $(\mathrm{p}<0.05)$ in the dosage of $160 \mathrm{mg} / 200 \mathrm{~g} \mathrm{bw}$./d of the EEAL compared to negative control groups (14.0 and 16.2) and similar to the positive control group, (methotrexate [15.2 and 11.0]). The 
reducing of blood lymphocytes level caused by suppression activity of the EEAL compared to the negative control group that observed on day 29 and 50; It showed, i.e.: In Dosage I: 9.0 and 7.8; Dosage II: 9.5 and 6.5; Dosage III: 11.1 and 7.4. There is a significant decrease in the levels of lymphocytes $(\mathrm{p}<0.05)$ on the three EEAL dosage variation treatment, compared with negative controls group (10.1 and 11.0). This observation shows similar results when compared to the positive control group (methotrexate [9.6 and 7.3])

\section{Effect on TNF- $\alpha$ concentration}

Effect of anti-RA activity of the EEAL against TNF- $\alpha$ concentration in the rat is shown in Fig. 4. TNF- $\alpha$ concentration suppression activity of the EEAL was analyzed by ELISA kit and was found $274.3 \mathrm{pg} / \mathrm{ml}$ in Dosage I, $236 \mathrm{pg} / \mathrm{ml}$ in Dosage II, and $244.3 \mathrm{pg} / \mathrm{ml}$ in Dosage III on day 50 . As shown in the results, concentration of TNF- $\alpha$ group AR rat model

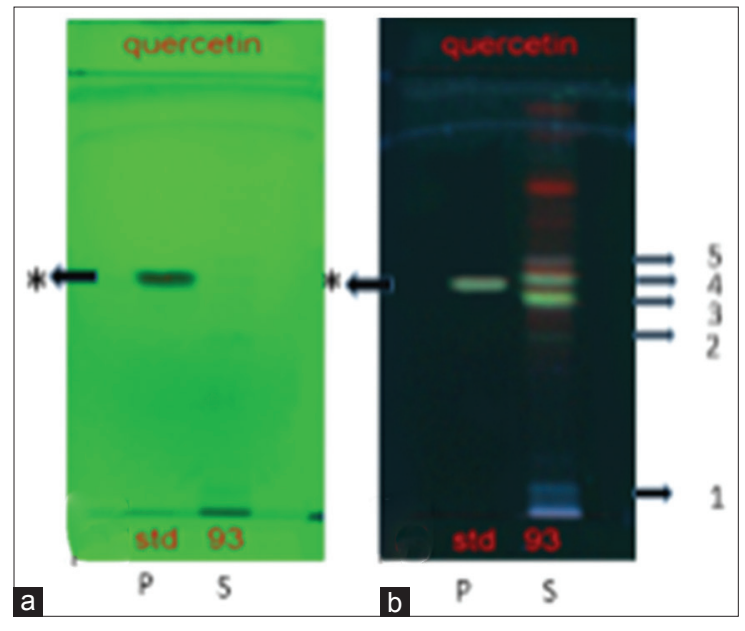

Fig. 1: Thin layer chromatography spotting of the ethanolic extract of Ageratum conyzoides L. leaves (EEAL). (a) Light $254 \mathrm{~nm}$

(b) light $366 \mathrm{~nm}$; $\mathrm{P}=$ Comparative quercetin, $\mathrm{S}=A$. conyzoides leaves extract, Asterisk $\left({ }^{*}\right) \mathbf{R f}=$ comparison value quercetin $\mathbf{0 . 5 2}$; Rf no. 4 (value of 0.53 )

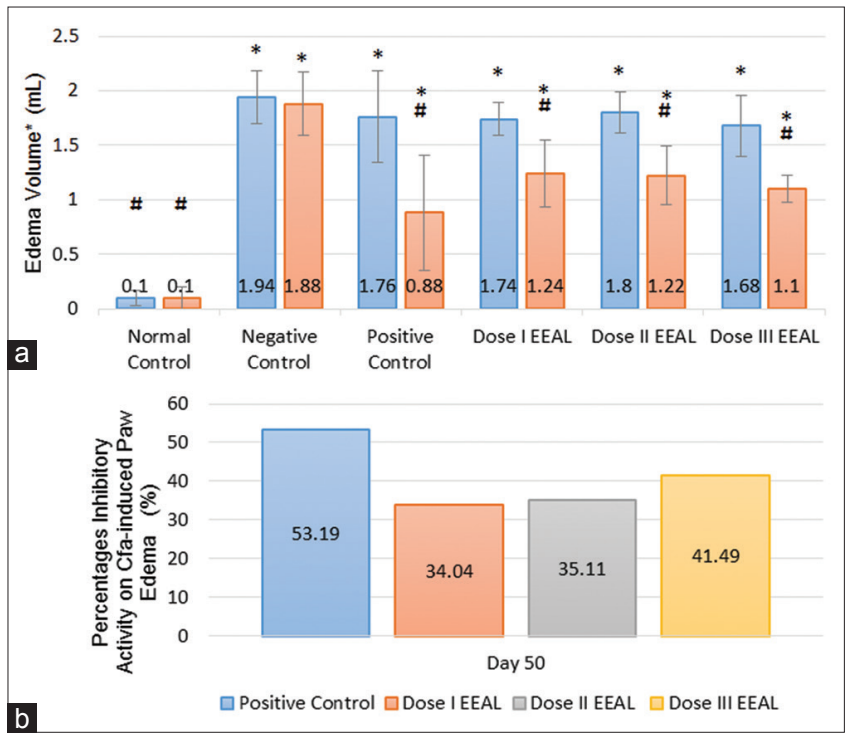

Fig. 2: (a) Anti-rheumatoid arthritis activity of the EEAL on CFA-induced paws edema in rats on day $29^{\text {th }}$ and $50^{\text {th }}$. Data are expressed as mean \pm standard deviation $(n=5)$. Statistical analysis was performed by one-way ANOVA and Kruskall-Wallis followed by multiple comparison tests ${ }^{*} \mathbf{p}<0.05$, (b) inhibitory activity of the HEAL on CFA-induced paw edema in rats on day $50^{\text {th }}$ increased when compared to normal control group. The concentration of TNF- $\alpha$ was reduced by the administration of three dose levels of the EEAL compared to the negative control group ( $316 \mathrm{pg} / \mathrm{ml}$ ) but higher than the positive control group, (methotrexate $[232.6 \mathrm{pg} / \mathrm{ml}]$ ). The EEAL showed inhibitory activity concentrations of TNF- $\alpha$ and it shows the anti-inflammatory effect on chronic inflammation.

Effect on number of osteoclasts

Observation number of osteoclasts in calcaneus bone by histopathology examination in rats induced CFA showed an increased amount compared with the normal control group. This result was a similar result in a previous study [18]. Anti-RA activity of three doses levels of

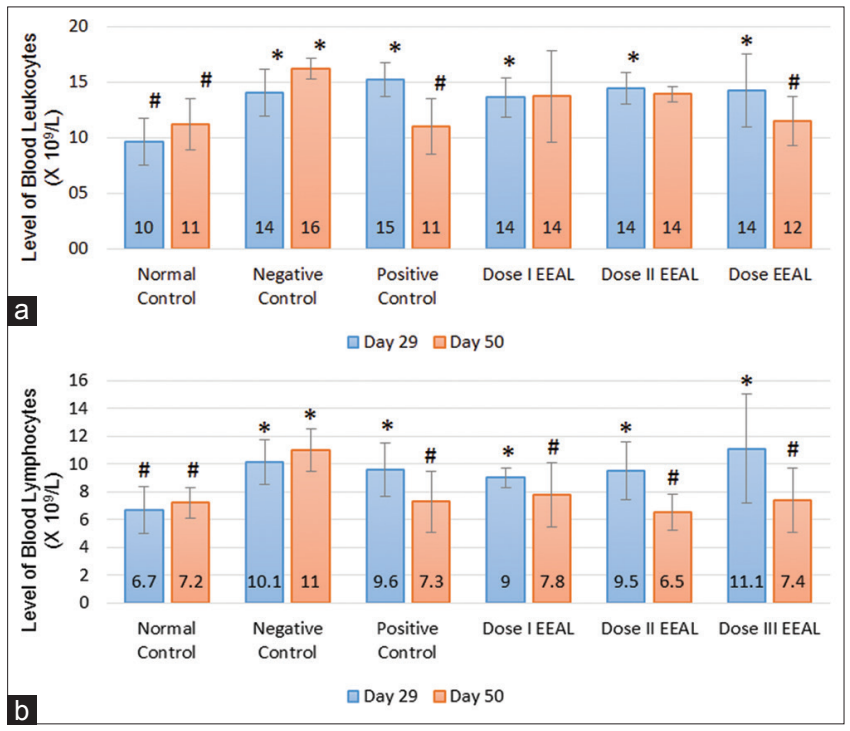

Fig. 3: Anti-rheumatoid arthritis activity of the EEAL on level of leukocytes and lymphocytes in rats in all treatment groups on day $29^{\text {th }}$ and $50^{\text {th }}$. (a) Level of leukocytes, (b) level of lymphocytes; data are expressed as mean \pm standard deviation $(n=5)$. Statistical analysis was performed by Kruskall-

Wallis followed by Mann Whitney's multiple comparison tests ${ }^{*} \mathbf{p}<0.05$

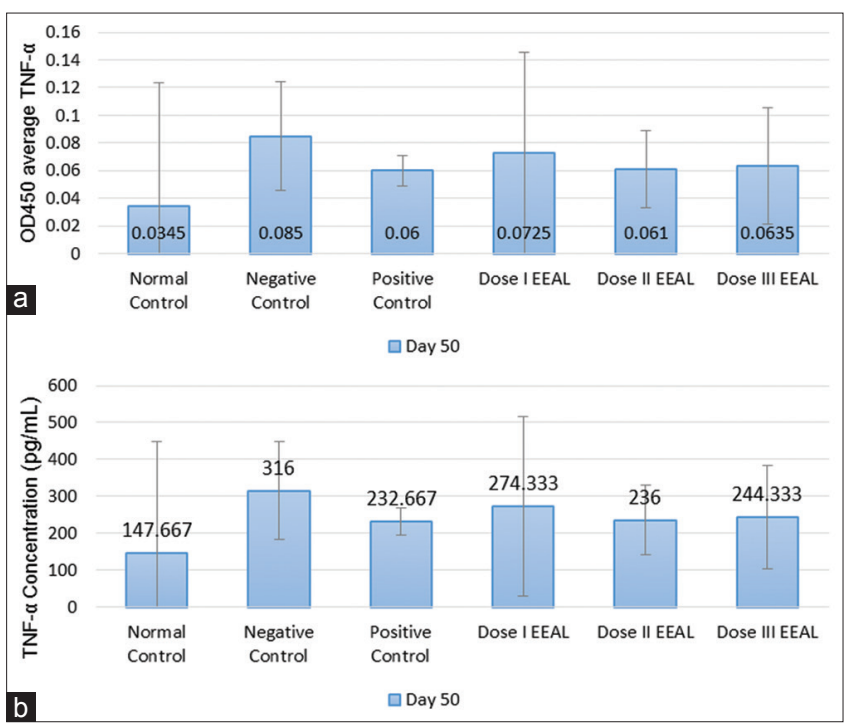

Fig. 4: Anti-rheumatoid arthritis activity of the EEAL on tumor necrosis factor- $\alpha$ titer in rats is shown in all treatment groups on day $50^{\text {th }}$. (a) OD450 tumor necrosis factor- $\alpha$ (TNF- $\alpha$ ) measurement, (b) TNF- $\alpha$ concentration measurement 
the EEAL proven to reduce the number of osteoclasts compared to the negative control group. After 21 days of treatment, the results showed the reducing number of osteoclasts was significant seen $(p<0.05)$ in the dosage of $160 \mathrm{mg} / 200 \mathrm{~g}$ bw./d of the EEAL compared to negative control groups. The total number of osteoclasts per $\mathrm{mm}^{2}$ in each group at day 50 was as shown in Fig. 5.

\section{DISCUSSION}

RA is a chronic inflammatory disease associated with the immune system. Inflammation begins with an increased of capillary permeability that allows the inflammatory cells (neutrophils and leukocytes) in the blood vessels to reach into inflammation areas which cause fluid influx. The body will attempt to stop the inflammatory process, but when the attempt went unsuccessful, the process will develop into a chronic inflammation. The chronic inflammation, usually associated with the immune system and which inflammatory cells such as mononuclear cells (lymphocytes and monocytes) will play a dominant role rather than PMN cells. In this study, a rat model induced by CFA containing $M$. tuberculosis. The CFA-induced arthritis rat model had extensively used as a laboratory model and has been reported successful to create RA rats model $[19,24,25]$. Rats were induced by CFA in the left hind paw subcutaneously on day 1 and then wait up to 4 weeks, to formed RA rats model [17].

A. conyzoides leaves were purchased in Bogor, Indonesia, where local communities traditionally use Babandotan leaves for the treatment of inflammatory disease in their daily live, such as fever, swelling, soreness, stiffness, wound, and abdominal discomfort. From preliminary screening, the result showed that the EEAL was containing various secondary metabolites such as flavonoids, tannins, alkaloids, terpenoids sterol, and saponins. Thin layer chromatography result showed flavonoids was equivalent to quercetin. Flavonoids have the core structure of the C6-C3-C6, two aromatic rings connected by $3 \mathrm{C}$ atoms, typically with $\mathrm{O}$ atoms bond which form a heterocyclic oxygen bond [26]. The mechanism of anti-inflammatory flavonoid can be explained in some way such as inhibiting the activity of the enzyme cyclooxygenase and lipooxygenase, inhibition of leukocyte accumulation, inhibition of neutrophil degranulation, histamine release, and inhibition anti-inflammatory activity (such as inhibiting production and activities pro-inflammatory cytokines). Quercetin, a member of flavonoids, has been extensively reviewed on its effects on inflammatory processes [27].

This study showed that the EEAL can inhibit the process of RA significantly in CFA-induced rat paw edema (especially in Dose III; $160 \mathrm{mg} / 200 \mathrm{~g}$ bw.) compared to the negative control group. The previous study by Moura et al., 2005, [4] showed that the hydroalcoholic extract of $A$. conyzoides leaves ( $250 \mathrm{mg} / \mathrm{kg}$ bw.; p.o.) had a $38 \%$ $(\mathrm{p}<0.05)$ reduction in cotton pellet granuloma and the development of

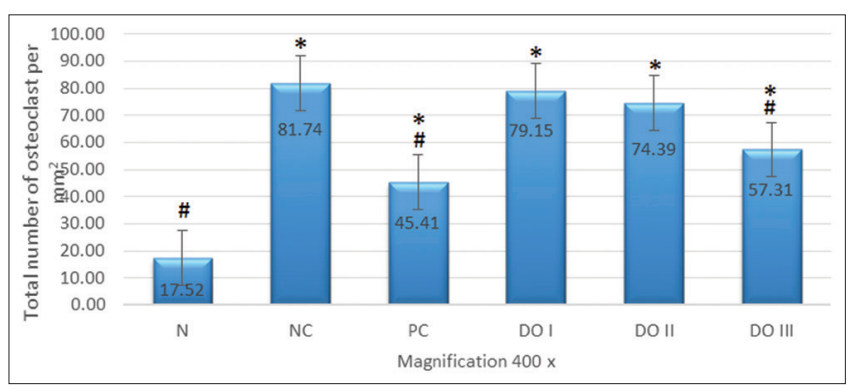

Fig. 5: Total number of osteoclast per $\mathrm{mm}^{2}$ in all treatment groups on day $50^{\text {th }}$. $\mathrm{N}=$ Normal controls, $\mathrm{NC}=$ Negative controls, PC=Positive controls, DO I=EEAL $40 \mathrm{mg} / 200 \mathrm{~g}$ bw./d, DO II=EEAL $80 \mathrm{mg} / 200 \mathrm{~g} \mathrm{bw} . / \mathrm{d}$, and DO III=EEAL $160 \mathrm{mg} / 200 \mathrm{~g}$ bw./d. Data are expressed as mean \pm standard deviation $(n=5)$. Statistical analysis was performed by Kruskall-Wallis followed by MannWhitney's multiple comparison tests * ${ }^{*}<0.05$ chronically induced paw edema was also reduced significantly $(\mathrm{p}<0.05)$ by the plant extract. Paw edema due to acute inflammation allowed the influx of inflammation cells and fluid into the inflamed area. The decrease of TNF- $\alpha$ concentration affects a decreased volume of paw edema, through inhibition of cyclooxygenase. The increased of paw edema inhibition of the EEAL showed that flavonoids had the antiinflammation effect through the mechanism of action in inhibiting the activity of inflammatory cells and pro-inflammation cytokines in CFAinduced rats. The EEAL dose used in the study was according to the previous studies [4] and was explained that hydroalcoholic extract of A. conyzoides has low toxicity/LD50 (>5.000 mg/kg, p.o) which make it relatively safe to use [5,28].

On the level of blood leukocytes test result, it is shown that giving the EEAL can reduce the level of blood leukocytes compared to negative control, as well as the blood lymphocytes because the inflammatory process that occurred was inhibited by flavonoids. Recent studies by Diallo et al., 2010, [28] showed flavonoid from the extract of $A$. conyzoides lowered white blood cells (WBC) in treated rats. CFA-injected in rats caused chronic inflammation, which makes the level of blood leukocyte and lymphocyte increased on day 29. The EEAL which contains flavonoids can inhibit the release of pro-inflammation cytokines such as TNF- $\alpha$ which can increase the infiltration of inflammatory cells into the inflamed area, that showed on day $50[4,29,30]$.

The treatment by giving the EEAL, which contained quercetin, can decrease the concentration levels of TNF- $\alpha$ compared to negative control. Previous studies by Nair et al. 2005 [27] explained that quercetin significantly inhibited TNF- $\alpha$ production and down-regulated gene expression in a dose-dependent manner. Anti-inflammation effect of quercetin by PBMCs (peripheral blood of mononuclear cells) which are mediated by inhibition of pro-inflammatory cytokine TNF- $\alpha$ via inhibiting activation of NF-kB. TNF- $\alpha$ is a pro-inflammatory cytokines which have an important role in the inflammatory process, such as increasing adhesion and infiltration of inflammatory cells into the inflamed area, increasing spending of other pro-inflammatory cytokines (such as IL-1, IL-2, and IFN- $\gamma$ ), increasing the occurrence of angiogenesis, thus simplifying the pannus and cause damage to the articular cartilage and bone so that further aggravate the state of RA [27,31].

In parameter on osteoclast counting, giving the EEAL can reduce the number of osteoclasts in calcaneus bone rats compared to negative control. The osteoclast is bone cells that play an important role in the absorption and bone regeneration [32]. Recent studies by Almarestani et al. 2011 [17] explained that induction CFA (1 mg/ml; 0,15 ml) subcutaneously in rats by day 15 showed joint and periarticular swelling with widened joint space at the MTP joints as an early sign of arthritis, and by day 30 showed soft tissue swelling, erosions, joint deformity, periosteal new bone formation, and trabecular bone thickness were further reduced. The increase of TNF- $\alpha$ concentration can elevate the amount of RANKL-RANK bond which also increases the production and activity of osteoclast, causing bone erosion that may worsen the RA disease [33-35]. Studies by Stolina et al. (2005) [36] showed that RANKL significantly increased during inflammatory arthritis in rats that associated with bone erosions and RANKL inhibition through OPG prevented local and systemic bone loss in arthritis models. Secondary metabolites such as flavonoids contained in the EEAL can inhibit the production and activity of TNF- $\alpha$, so there was no excessive increase in the number and activity of osteoclasts.

\section{CONCLUSION}

The EEAL harvested from Bogor, Indonesia has an activity of anti-RA in rats model, and flavonoids play an important role in inhibiting the progressivity of RA disease. These results also corroborate experimental evidence of traditional usage of $A$. conyzoides L. (Babandotan) leaves by local communities in Bogor, Indonesia in handling various inflammatory diseases, particularly RA. 


\section{ACKNOWLEDGMENTS}

The authors would like to acknowledge to Ministry of Research Technology and Higher Education of Indonesia for supporting this research.

\section{Graphical abstract}

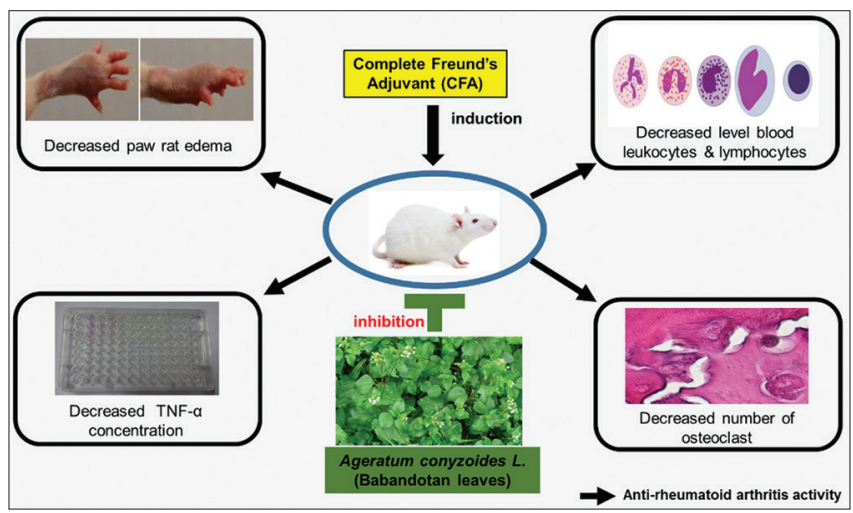

\section{REFERENCES}

1. Okunade AL. Ageratum conyzoides L. (Asteraceae). Fitoterapia 2002;73(1):1-16

2. Kamboj A, Saluja AK. Isolation of stigmasterol and B-sitosterol from petroleum ether extract of aerial parts of Ageratum conyzoides (Asteraceae). IJPPS 2011;3(1):94-6.

3. Singh SB, Devi WR, Marina, Devi WI, Swapana N, Singh CB. Ethnobotany, phytochemistry and pharmacology of Ageratum conyzoides Linn (Asteraceae). J Med Plants Res 2013;7(8):371-85.

4. Moura AC, Silva EL, Fraga MC, Wanderley AG, Afiatpour P, Maia MB. Antiinflammatory and chronic toxicity study of the leaves of Ageratum conyzoides L. in rats. Phytomedicine 2005;12(1-2):138-42.

5. Hassan MM, Shahid-ud-Daula AF, Jahan IA, Nimmi I, Adnan T, Mansur AA, et al. Anti-inflammatory activity, total flavonoid and tannin content from ethanolic extract of Ageratum conyzoides Linn. Leaf. IJPPR. 2012;1(5):234-41.

6. Nathiya S, Durga M, Thiyagarajan, D. Quercetin, encapsulated quercetin and its application - A review. IJPPS 2014;6(10):20-6.

7. Amadi BA, Duru MK, Agomuo EN. Chemical profiles of leaf, stem, root and flower of Ageratum conyzoides. AJPSR 2012;2(4):428-32.

8. Okoli CO, Akah PA, Nwafor SV. Review, anti-inflammatory activity of plants. J Nat Remed 2003;3(1):1-30.

9. Mehta A, Sethiya NK, Mehta C, Shah GB. Anti-arthritis activity of roots of Hemidesmus indicus R.Br. (Anantmul) in rats. Asian Pac J Trop Med 2012;5(2):130-5

10. Paul S, Das AP, Bhattacharjee S. Rheumatoid arthritis: Molecular basis and cures from nature. IJPPS 2015; 7(7):30-9.

11. Schuna AA. In: Dipiro JT, Talbert RL, Yees GC, Matzke GR, Wells BG, Posey LM, editors. Pharmacotherapy, A Pathophysiologic Approach: Rheumatoid Arthritis. $6^{\text {th }}$ ed. New York: Mc Graw-Hill Company; 2005. p. $1670-82$.

12. Aletaha D, Kapral T, Smolen JS. Toxicity profile of traditional disease modifying anti-rheumatic drugs for rheumatoid arthritis. Ann Rheum Dis 2003;62(5):482-6

13. Integrated Licensing Agency Bogor District. Climate. PBT Bogor City. Available from: http://www.Lipse.bpt.bogorkab.go.id $>$ invest $>$ iklim. 15 September 2016. $04.50 \mathrm{am}$.

14. Awad NE, Kassem HA, Elkhayat ZA, El-Feky AM, Matloub AA. Chemical composition and anti-inflammatory evaluation of Ageratum conyzoides L. leaves. JASR 2013:9(3):2126-34.

15. Almarestani L, Fitzcharles MA, Bennett GJ, Ribeiro-da-Silva A. Imaging studies in Freund's complete adjuvant model of regional polyarthritis, a model suitable for the study of pain mechanisms, in the rat. Arthritis Rheum 2011;63(6):1573-81.

16. Bahtiar A, Nakamura T, Kishida K, Katsura J, Nitta M, Ishida-
Kitagawa N, et al. The 1-Ser analog \#290 promotes bone recovery in OP and RA mice. Pharmacol Res 2011;64(3):203-9.

17. Bolon B, Stolina M, King C, Middleton S, Gasser J, Zack D, et al. Rodent preclinical models for developing novel anti arthritic molecules: Comparative biology and preferred methods for evaluating efficacy. Hindawi Publ Corp J Biomed Biotechnol 2011. DOI: $10.1155 / 2011 / 569068$

18. Bolon B, Morony S, Cheng Y, Hu YL, Feige U. Osteoclast number in lewis rats with adjuvant-induced arthritis identification of preferred sites and parameters for rapid quantitative analysis. Vet Pathol 2004;41:30-6.

19. Ministry of Health of the Republic of Indonesia. Herbal Pharmacopoeia of Indonesia. $1^{\text {st }}$ ed. (Supplement II) Jakarta: Ministry of Health of the Republic of Indonesia; 2011

20. Ministry of Health of the Republic of Indonesia. Materia Medika Indonesia. Vol. VI. Jakarta: Ministry of Health of the Republic of Indonesia; 1995.

21. Ministry of Health of the Republic of Indonesia. Parameters Standard General Extracts Plant Medicine. Directorate General of Drug and Food Control. Traditional Drug Control Directorate. Jakarta: Bakti Husada; 2000

22. Nagakura $\mathrm{Y}$, Okada M, Kohara A, Kiso T, Toya T, Iwai A, et al. Allodynia and hyperalgesia in adjuvant-induced arthritic rats: Time course of progression and efficacy of analgesics. J Pharmacol Exp Ther 2003;306(2):490-7

23. Bevaart L, Vervoordeldonk MJ, Tak PP. Evaluation of therapeutic targets in animal models of arthritis: How does it relate to rheumatoid arthritis? Arthritis Rheum 2010;62(8):2192-205.

24. Hanani E. Phytochemical Analysis. Jakarta: Book Medical Publishers EGC; 2016.

25. Nair MP, Mahajan S, Reynolds JL, Aalinkeel R, Nair H, Schwartz SA, Kandaswami C. The flavonoid quercetin inhibits proinflammatory cytokine (Tumor necrosis factor-alpha) gene expression in normal peripheral blood mononuclear cells via modulation of the NF-kB system. Clinical and vaccine immunology. 2006;13(3):319-28.

26. Diallo A, Gadegkeku KE, Agbonon A, Aklikokou K, Creppy EC, Gbeassor M. Acute and sub-chronic (28 days) oral toxicity studies of hidroalcoholic leaf extract of Ageratum conyzoides L. (Asteraceae). TJPR 2010;9(5):463-7.

27. Nijveldt RJ, van Nood E, van Hoorn DE, Boelens PG, van Norren K, van Leeuwen PA. Flavonoids: A review of probable mechanisms of action and potential applications. Am J Clin Nutr 2001;74(4):418-25.

28. Durga M, Nathiya S, Devasena T. Immunomodulatory and antioxidant actions of dietary flavonoids. Int J Pharm Pharm Sci 2014;6(2):50-6.

29. Chen CC, Chow MP, Huang WC, Lin YC, Chang YJ. Flavonoids inhibit tumor necrosis factor-alpha-induced up-regulation of intercellular adhesion molecule-1 (ICAM-1) in respiratory epithelial cells through activator protein-1 and nuclear factor-kappaB: Structure-activity relationships. Mol Pharmacol 2004;66(3):683-93.

30. Miyamoto T, Suda T. Review: Differentiation and function of osteoclasts. Keio J Med 2002;52(1):1-7.

31. Braun T, Zwerina J. Positive regulation of osteoclastogenesis and bone resorpsion in rheumatoid arthritis. Arthritis Res Ther 2011;13(4):235.

32. Udagawa N, Kotake S, Kamatani N, Takahashi N, Suda T. The molecular mechanism of osteoclastogenesis in rheumatoid arthritis. Arthritis Res 2002:4:281-9.

33. Karmakar S, Kay J, Gravallese EM. Bone damage in rheumatoid arthritis: Mechanistic insights and approaches to prevention. Rheum Dis Clin North Am 2010;36(2):385-404.

34. Stolina M, Adamu S, Ominsky M, Dwyer D, Asuncion F, Geng Z, et al. RANKL is a marker and mediator of local and systemic bone loss in two rat models of inflammatory arthritis. J Bone Miner Res 2005;20(10):1756-65.

35. Schett G, Gravallese E. Bone erosion in rheumatoid arthritis: mechanisms, diagnosis and treatment. Nature Reviews Rheumatology. 2012;8(11):656-64

36. Stolina M, Schett G, Dwyer D, Vonderfecht S, Middleton S, Duryea D, Pacheco E, Van G, Bolon B, Feige U, Zack D. RANKL inhibition by osteoprotegerin prevents bone loss without affecting local or systemic inflammation parameters in two rat arthritis models: comparison with anti-TNF $\alpha$ or anti-IL-1 therapies. Arthritis research \& therapy. 2009;11(6):1. 